\title{
PENGELOLAAN TATA AIR UNTUK MENDUKUNG PERTANIAN TERPADU DI DESA LANGSAT PERMAI KECAMATAN BUNGA RAYA KABUPATEN SIAK
}

\author{
Hapsoh $^{1}$, Wawan ${ }^{1}$, Isna Rahma Dini ${ }^{1 *}$ \\ ${ }^{1}$ Jurusan Agroteknologi, Fakultas Pertanian, Universitas Riau, Pekan Baru, Indonesia \\ *Penulis Korespondensi : isnarahmadini19@gmail.com
}

\begin{abstract}
Abstrak
Rendahnya produktivitas tanaman padi maupun hortikultura di desa Langsat Permai Kecamatan Bunga Raya Kabupaten Siak salah satunya disebabkan karena belum tersedianya air yang cukup untuk budidaya tanaman sehingga perlu dilakukan pengelolaan tata air dengan pembuatan canal blocking untuk dapat dimanfaatkan pada tanaman padi maupun tanaman hortikultura di daerah tersebut. Hal ini dilakukan untuk memenuhi kebutuhan air pada tanaman padi maupun hortikultura apalagi pada saat musim kemarau. Oleh karena itu, dilakukan pendampingan melalui kegiatan IbDM pengelolaan tata air di Desa Langsat Permai Kecamatan Bunga Raya Kabupaten Siak. Selain pengadaan air, peningkatan budidaya pertanian dapat dilakukan dengan memanfaatkan limbah jerami untuk dijadikan kompos dan pakan ternak sehingga dapat membentuk pertanian terpadu antara aspek pertanian dan peternakan. Strategi pendampingan dilakukan dengan berdiskusi secara langsung dengan kelompok tani mengenai dampak pembuatan canal blockingdan praktek langsung dalam pembuatan kompos dan pakan ternak. Melalui kegiatan ini sangat terlihat antusias masyarakat dalam pelaksanaan kegiatan IbDM yang dilakukan melalui peningkatan motivasi masyarakat untuk pengembangan tanaman pangan dan hortikultura serta lebih memanfaatkan jerami padi untuk kompos dan pakan ternak.
\end{abstract}

Kata Kunci : canal blocking, jerami padi, kompos, pakan ternak

\begin{abstract}
The low productivity of rice crops and horticulture in Langsat Permai village, Bunga Raya subdistrict, Siak regency is caused by the lack of sufficient water for the cultivation of plants, so it is necessary to manage the water system by making canal blocking to be used in rice crops and horticultural crops in the area. This is done to meet the water needs in rice crops and horticulture especially during the dry season. Therefore, assistance is done through the activities of IbDM water management in the Village Langsat Permai District Bunga Raya Siak District. In addition to water supply, improved agricultural cultivation can be done by utilizing the waste of straw to be used as compost and animal feed so as to form an integrated agriculture between aspects of agriculture and livestock. Advisory strategy is conducted by discussing directly with farmer groups about the impact of canal blocking and direct practice in composting and animal feed. Through this activity is very visible enthusiastic community in the implementation of IbDM activities conducted through increased community motivation for the development of food crops and horticulture and more use of rice straw for compost and animal feed.
\end{abstract}

Keywords: Canal Blocking, Rice Straw, Compost, Animal Feed

\section{PENDAHULUAN}

Provinsi Riau merupakan salah satu provinsi yang mengembangkan usaha perkebunan sawit jauh lebih banyak dibandingkan dengan pertanian tanaman pangan. Selama ini lahan yang tersedia di Provinsi Riau dikonversi menjadi lahan perkebunan. Hal ini disebabkan karena pola pikir masyarakat Riau yang menyatakan bahwa usaha perkebunan khususnya sawit lebih menguntungkan daripada tanaman pangan. Ini berkaitan dengan indeks pertanaman padi hanya satu kali dalam satu tahun (IP 100) sehingga dirasa kurang menguntungkan apabila mengembangkan tanaman pangan. Padahal kebutuhan pangan di Pekanbaru khususnya beras masih didatangkan dari Provinsi tetangga yaitu Sumatera Barat. Oleh karena itu, perlu dilakukan upaya untuk mendorong masyarakat Riau di berbagai daerah untuk mengembangkan usaha pertanian pangan maupun hortikultura dibandingkan dengan usaha perkebunan sehingga dapat memenuhi kebutuhan masyarakat di daerah Provinsi Riau sendiri. 
Desa Langsat Permai merupakan salah satu desa di Kecamatan Bunga Raya yang memiliki potensi untuk pengembangan tanaman pangan maupun tanaman horikultura. Sebagian lahan di Desa Langsat Permai sudah dilakukan budidaya tanaman pangan dan sebagian lagi diupayakan untuk tanaman perkebunan. Namun, dalam beberapa tahun terakhir, masyarakat Desa Langsat Permai sudah banyak beralih pada usaha budidaya tanaman pangan.

Ketersediaan lahan yang cukup optimal untuk pengembangan usaha budidaya tanaman pangan mengakibatkan desa ini menjadi lokasi pengembangan tanaman pangan untuk beberapa jenis tanaman pangan seperti padi, jagung, kacang panjang, dan ubi kayu. Dari sekian tanaman pangan tersebut yang paling banyak dibudidayakan yaitu tanaman padi. Jenis padi yang dibudidayakan oleh masyarakat desa setempat yaitu padi sawah dengan luas $102 \mathrm{Ha}$ dengan produktivitas 255 ton/Ha atau dengan kata lain dapat memproduksi 2,5 ton dalam 1 Ha lahan padi.

Permasalahan yang dihadapi pada pengembangan tanaman padi di Desa Langsat Permai yaitu indeks pertanaman tanaman padi yang diusahakan hanya satu kali dalam setahun (IP 100). Oleh karena itu perlu dilakukan upaya untuk meningkatkan indeks pertanaman menjadi dua sampai tiga kali dalam satu tahun (IP 200/ IP 300) sehingga nantinya dapat meningkatkan produktivitas tanaman padi dan meningkatkan pendapatan masyarakat di Desa Langsat Permai. Produktivitas tanaman padi dapat terus dikembangkan jika dikelola dengan sistem pertanian yang baik. Salah satunya dengan memberikan kebutuhan tanaman berupa air dan nutrisi (unsur hara) tanaman agar tercapai pertumbuhan yang optimal.

Selama ini, kebutuhan air untuk tanaman padi di Desa Langsat Permai tidak dilakukan secara optimal karena air tidak begitu banyak tersedia untuk mengairi sawah yang diusahakan. Hal ini akan lebih parah lagi jika penanaman dilakukan pada musim kemarau yang akan menyebabkan terjadi permasalahan yaitu tidak tersedianya air sehingga petani mengalami kesulitan dalam penyediaan air. Hal ini tentu saja dapat mempengaruhi terhambatnya usaha pertanian di desa tersebut. Sehingga sangat diperlukan upaya untuk dapat mengatasi permasalahan kebutuhan air tersebut yaitu dengan pengelolaan tata air yang baik.

Di sekitar lahan budidaya di Desa Langsat Permai terdapat kanal yang selama ini belum dimanfaatkan dan hanya dibiarkan mengalir begitu saja. Oleh karena itu, perlu dilakukan pembuatan canal blocking. Aliran air di kanal di sekitar lahan budidaya diberi sekat pembatas sehingga air tertampung dan nantinya dapat digunakan untuk tanaman padi maupun tanaman lainnya dengan menggunakan pompa untuk menarik air dari kanal tersebut. Melalui pengelolaan air yang baik, maka usaha pertanian tanaman pangan khususnya padi yang dilakukan dapat berkembang dan tentu saja akan dapat meningkatkan pendapatan masyarakat di desa tersebut. Dengan upaya tersebut, secara tidak langsung dapat mengubah pola fikir dan pengetahuan masyarakat petani di Desa Langsat Permai untuk lebih mengembangkan tanaman pangan dibandingkan dengan tanaman sawit.

Selain pengelolaan air yang baik, hal lain yang dapat meningkatkan produktivitas tanaman pangan yaitu pupuk. Pupuk merupakan unsur yang sangat penting dibutuhkan oleh tanaman dalam menunjang pertumbuhannya. Petani di Desa Langsat Permai biasanya menggunakan pupuk kandang maupun pupuk non organik pada usaha budidaya tanaman yang dilakukan. Pupuk kandang yang digunakan oleh petani setempat dibeli dari desa lain. Penggunaan pupuk kandang pada usaha pertanian yang dilakukan mengalami beberapa kelemahan yaitu besarnya biaya produksi usaha pertanian yang dilakukan. Selain itu, jumlah pupuk kandang yang dibutuhkan petani Desa Langsat Permai sangat terbatas sehingga dapat mempengaruhi usaha pertanian yang dilakukan. Oleh karena itu, upaya yang dapat dilakukan yaitu dengan membuat pupuk organik dengan memanfaatkan bahan organik yang ada seperti limbah jerami padi.

Selama ini, limbah jerami padi di Desa Langsat Permai tidak dimanfaatkan dan hanya dibuang begitu saja. Bahkan sebagian petani membakar limbah tersebut. Oleh karena itu perlu dilakukan upaya untuk memanfaatkan limbah jerami padi salah satunya yaitu menjadi pupuk kompos dan pakan fermentasi untuk ternak yang juga terdapat di desa tersebut.

Pupuk kompos merupakan pupuk yang berasal dari hasil penguraian bahan organik seperti limbah pertanian dengan menggunakan mikrob dekomposer menjadi senyawa sederhana yang dapat memenuhi kebutuhan tanaman. Mikrob dekomposer pembuatan kompos dapat berasal dari EM4 atau suplemen mikrob yang sudah banyak di pasaran. Melalui usaha peternakan yang juga terdapat di Desa Langsat Permai maka dapat memanfaatkan kotorannya sebagai sumber mikrob pengurai dalam menguraikan jerami padi menjadi kompos.

Sementara itu, pakan fermentasi dari limbah jerami padi dapat berpeluang untuk ternak yang dimiliki oleh masyarakat di Desa Langsat Permai di mana di desa tersebut juga memiliki usaha peternakan sebanyak 250 ekor sapi. Namun, pemanfaatan limbah jerami secara langsung atau sebagai pakan tunggal tidak dapat memenuhi pasokan nutrisi yang dibutuhkan oleh ternak. Selain itu, kendala lainnya dalam pemanfaatan limbah jerami untuk pakan disebabkan karena ternak kurang menyukai limbah jerami padi. Hal ini disebabkan karena kandungan serat kasar yang tinggi pada jerami dan protein yang sulit dicerna oleh ternak. Hal ini sesuai dengan 
pendapat Ranjhan (1977) yang menyatakan bahwa limbah jerami padi memiliki kandungan gizi yang rendah di antara lain yaitu rendahnya kandungan proten kasar, tingginya serat kasar, lignin, dan silika serta rendahnya kecernaan (Djajanegara, 1986). Namun, limbah jerami masih mengandung sekitar $80 \%$ zat-zat potensial yang dapat dicerna sebagai sumber energi bagi ternak.

Pemanfaatan limbah jerami padi untuk pakan ternak sangat berpotensi apalagi pada saat musim kemarau di mana pasokan rumput sebagai pakan ternak utama tidak bisa memenuhi kebutuhan pakan ternak. Untuk mengatasi berbagai kendala dalam pemanfaatan limbah jerami padi dapat dilakukan dengan teknologi fermentasi limbah jerami atau dikenal dengan bioteknologi limbah jerami (Yunilas, 2009).

Fermentasi jerami padi dapat dilakukan oleh mikrob yang dapat mendegradasi jerami melalui enzim yang dihasilkan oleh mikrob tersebut sehingga dapat memperbaiki kualitas jerami yang telah difermentasi seperti peningkatan kandungan nutrisi pada limbah jerami padi setelah fermentasi. Pemanfaatan pakan dari limbah jerami hasil fermentasi dapat meningkatkan pemenuhan kebutuhan pakan ternak di Desa Langsat Permai. Artinya selain memnafaatkan limbah jerami yang belum termanfaatkan, dampak positif lainnya yaitu meningkatkan usaha peternakan di desa tersebut.

Melalui kegiatan tersebut, maka dapat memberikan peluang besar dalam mendukung pertanian terpadu di mana terjadi penggabungan antara usaha pertanian, perkebunan, dan peternakan yang memberikan nilai tambah untuk pengembangan pertanian terpadu di masyarakat desa Langsat Permai Kecamatan Bunga Raya Kabupaten Siak.

\section{BAHAN DAN METODE}

Metode penerapan kegiatan pembinaan di Desa Langsat Permai Kecamatan Bunga Raya dilakukan dengan beberapa tahapan di antaranya yaitu:

a. Pembinaan kelompok sasaran terhadap pentingnya tanaman pangan untuk memenuhi kebutuhan masyarakat di Provinsi Riau;

b. Pembinaan kelompok sasaran dalam pembuatan canal blocking di sekitar lahan pertanian;

c. Pembinaan kelompok sasaran dengan memberikan materi tentang pemanfaatan limbah jerami padi untuk pakan ternak dan pupuk organik untuk tanaman hortikultura;

d. Pembuatan rumah kompos untuk pengolahan limbah jerami dan limbah pertanian lainnya pada satu kelompok tani;

e. Peningkatan usaha peternakan melalui pembuatan rumah pakan fermentasi dan penambahan hewan ternak;

f. Melakukan evaluasi kegiatan pengabdian yang dilakukan. Indikator keberhasilan yaitu pengelolaan ait di lahan sawah yang baik, peningkatan produktivitas tanaman pangan dan hortikultura, peningkatan pengetahuan petani tentang cara fermentasi pakan ternak dan pupuk menggunakan limbah jerami padi.

\section{HASIL DAN PEMBAHASAN}

Pengabdian masyarakat yang dilakukan di Desa Langsat Permai Kecamatan Bunga Raya dilakukan karena produksi pertanian tanaman pangan khususnya padi belum optimal. Pembuatan canal blocking ditujukan untuk mencukupi kebutuhan air untuk kegiatan pertanian pangan khususnya padi. Pembuatan canal blocking ini sangat efektif untuk menyediakan air pada musim kemarau sehingga usaha budidaya petani dapat dilakukan. Pengabdian yang dilakukan sangat mendapat respon positif dari anggota kelompok tani setempat. Hal ini tergambar dengan antusias mereka dalam membangun kanal dengan melibatkan semua anggota kelompok tani (Gambar 1).
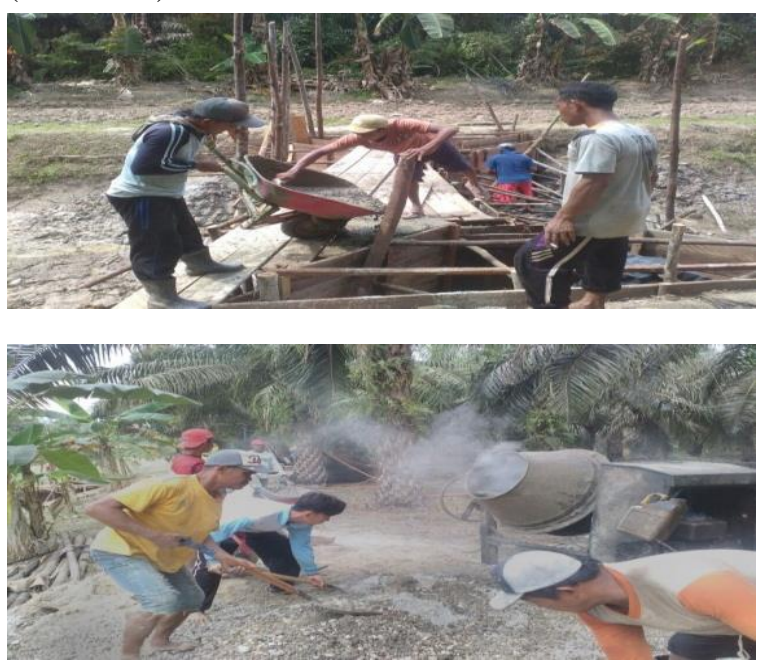

Gambar 1. Petani sedang bergotong royong membuat canal blocking

Pada saat pembuatan canal blocking didampingi dengan anggota peneliti untuk melihat perkembangan canal yang sedang dibuat (Gambar 2).

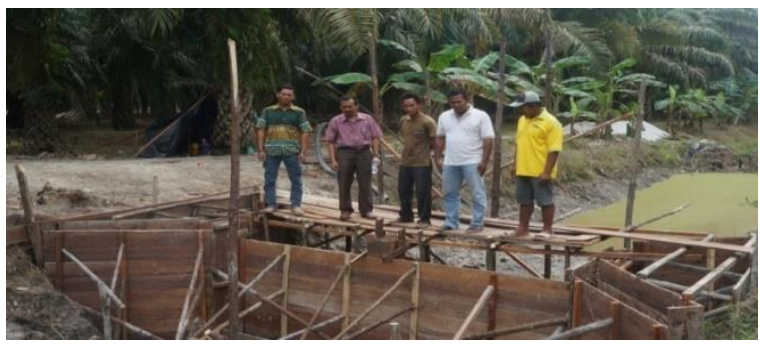

Gambar 2. Anggota penelitian sedang meninjau pembuatan canal blocking

Setelah dilakukan dilakukan pengecoran, canal blocking sudah siap untuk digunakan oleh masyarakat agar dapat dimanfaatkan untuk budidaya tanaman pangan maupun hortikultura (Gambar 3). Tata kelola pemanfaatan canal blocking diuraikan melalui peta 
yang menerangkan skema pengaliran air yang berasal dari air hutan rawa gambut dan selanjutnya akan dimanfaatkan untuk budidaya tanaman (Gambar 4).

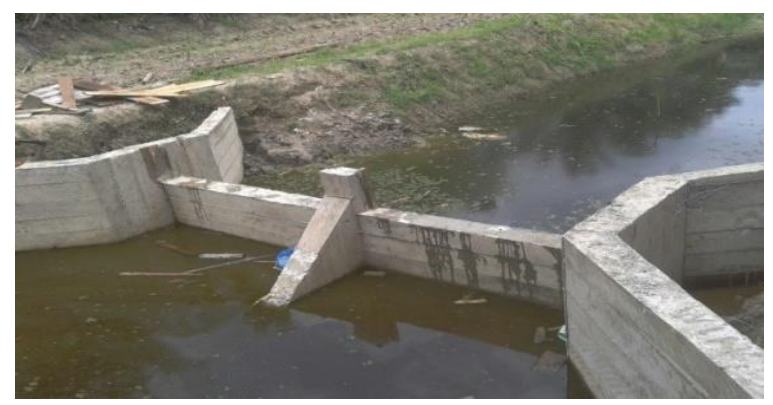

Gambar 3. Canal blocking yang siap digunakan untuk menampung air

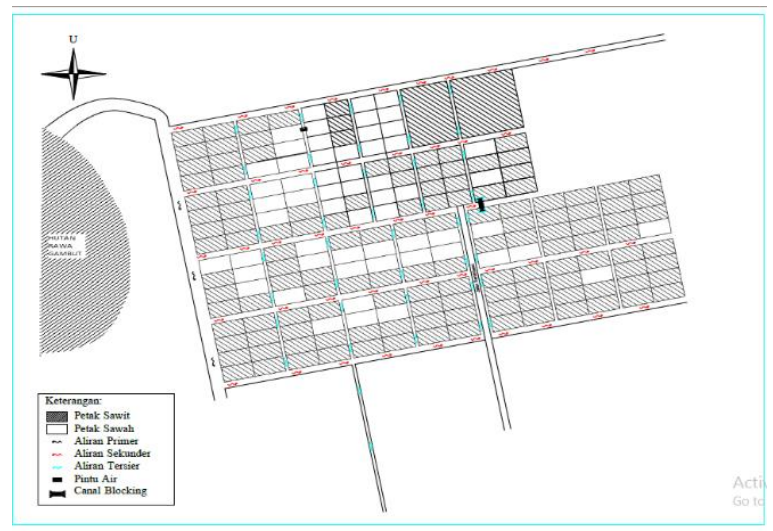

Gambar 4. Tata kelola air melalui pembuatan canal blocking

Selain mengamati pembuatan canal blocking, aspek penggunaan saprodi usaha tani juga diamati yang meliputi penggunaan benih, penggunaan pupuk, dan pengendalian hama penyakit menunjukkan bahwa semua petani padi sawah di Desa Langsat Permai Kecamatan. Semua petani menggunakan pupuk urea, KCL dan NPK, 89,6\% petani menggunakan pupuk TSP serta $79,1 \%$ petani menggunakan pupuk TSP. Semua petani padi di Langsat Permai Kecamatan Bunga Raya sudah melakukan pengendalian hama dan penyakit tanaman dengan pengaplikasian pestisida, herbisida dan insektisida.

Informasi yang diperoleh dari petani pada sawah di Langsat Permai Kecamatan Bunga Raya tentang aspek penanaman dan pemeliharaan menunjukkan bahwa Rata-rata petani melakukan persemaian di sawah dengan rata-rata luas area semai adalah 9,3 $\mathrm{m}^{2}$. Pembersihan lapangan dilakukan petani dengan cara penyemprotan menggunakan herbisida. Petani padi sawah di Langsat Permai memiliki rerata luas lahan yakni 1 ha. Pada kegiatan persiapan lahan terdiri dari kegiatan pengolahan tanah 1 dan 2. Pengolahan tanah dilakukan petani dengan menggunakan mesin traktor. Teknik penanaman yang dilakukan petani adalah dengan cara tanam bibit. Satu lubang tanam terdiri atas 3 bibit dengan rata-rata jarak tanam adalah 25 cm. Pengaturan air dilakukan secara diesel atau pompanisasi. Beberapa kendala pada kegiatan pengairan menurut petani diantaranya adalah mesin rusak dan TMA kanal. Kegiatan penyiangan masih minim dilakukan oleh petani.

Distribusi jawaban petani untuk aspek pengendalian hama dan penyakit memperlihatkan bahwa hama yang dominan menyerang tanaman padi petani pada fase vegetative adalah ulat penggulung daun dan kepinding tanah, sedangkan pada fase generative adalah hama sundep dan wereng coklat. Penyakit yang dominan menyerang tanaman padi petani pada vegetative adalah penyakit blast, sedangkan pada fase generative adalah penyakit patah leher.

Pada aspek panen dan pasca panen diketahui bahwa semua petani menggunakan alat panen yakni mesin combine havester. Alat perontok padi adalah mesin perontok sedangkan alat pembersih masih dilakukan secara manual. Kegiatan penyimpanan hanya dilakukan menjelang digiling dan dijual. Pada aspek pemasaran diketahui kondisi harga tertinggi dan terendah untuk beras dan gabah. Harga gabah tertinggi dan terendah adalah Rp.4.300 dan Rp. 3.800, sedangkan untuk beras adalah Rp. 9.500 dan Rp.8.500. Mayoritas petani padi melakukan pemasaran hasil panen masih dalam bentuk gabah yang dijual kepada pedagang pengumpul (Pemborong). Rata-rata besar penerimaan yang diperoleh petani pada musim tanam I adalah Rp. 16.614.000 dan pada musim tanam II adalah Rp. 16.463.000 dengan luas lahan rata-rata adalah 1 ha.

\section{KESIMPULAN}

Berdasarkan hasil kegiatan IbDM pengelolaan tata air untuk mendukung pertanian terpadu yang telah dilaksanakan, maka dapat disimpulkan sebagai berikut :

- Pada saat kegiatan pengabdian dilakukan, antusias para petani sudah terlihat dari awal pelaksanaan sampai pada akhir pelaksanaan. Masyarakat aktif berdiskusi dengan tim pengabdian maupun turun langsung membantu dalam kegiatan yang dilakukan. Pembuatan canal blocking dilakukan secara bergotong royong oleh petani setempat sehingga pemanfaatan air dari kanal tersebut telah dapat dimanfaatkan oleh petani khususnya jika musim kemarau tiba.

- Para petani setempat belum optimal memanfaatkan limbah jerami padi. Kegiatan pengabdian sangat bermanfaat sekali bagi petani dalam memanfaatakan limbah jerami padi untuk pupuk kompos dan pakan ternak. Melalui pembuatan rumah kompos yang akan dibangun dapat memberikan motivasi masyarakat dalam pembuatan pupuk organik sehingga dapat mengembangkan pertanian organik di desa tersebut. 


\section{UCAPAN TERIMA KASIH}

Terima kasih disampaikan kepada Dikti melalui Program Pengembangan Desa Mitra yang telah mendanai kegiatan pengabdian ini.

\section{DAFTAR PUSTAKA}

Djajanegara, A. 1983. Tinjauan ulang mengenai evaluasi suplemen pada jerami padi. Prosiding Seminar Pemanfaatan Limbah Pangan dan Limbah Pertanian untuk Makanan Ternak. Bandung: Lembaga Kimia Nasional LIPI.

Ranjhan, S.K. 1977. Animal Nutrition and Feeding Practice ini India. New Delhi: Vikan Pub. House PVT Ltd.

Yunilas. 2009. Bioteknologi jerami padi melalui fermentasi sebagai bahan pakan ternak ruminansia. Karya Ilmiah Departemen Peternakan Fakultas Pertanian Universitas Sumatera Utara. Medan. 